\title{
Crystallization and Preliminary X-Ray Diffraction Studies of Mandelonitrile Lyase From Almonds
}

\author{
Hanspeter Lauble, ${ }^{1}$ Kirsten Müller, ${ }^{1}$ Hermann Schindelin, ${ }^{2}$ Siegfried Förster, ${ }^{1}$ and Franz Effenberger \\ ${ }^{1}$ Institut für Organische Chemie und Isotopenforschung, Universität Stuttgart, D-70569 Stuttgart, Germany and \\ ${ }^{2}$ Institut für Kristallographie, Freie Universität Berlin, D-14195 Berlin, Germany
}

\begin{abstract}
Single crystals of three different isoenzymes of $(R)-(+)$ mandelonitrile lyase (hydroxynitrile lyase) from almonds (Prunus amygdalus) have been obtained by hanging drop vapor diffusion using polyethylene glycol 4000 and isopropanol as co-precipitants. The crystals belong to the monoclinic space group P2 1 with unit cell parameters $a=69.9, b=95.1$, $c=95.6 \AA$, and $\beta=118.5^{\circ}$. A complete set of diffraction data has been collected to $2.6 \AA$ resolution on native crystals of isoenzyme III.

(1) 1994 Wiley-Liss, Inc.
\end{abstract}

Key words: hydroxynitrile lyase, flavoenzyme, X-ray crystallography

\section{INTRODUCTION}

Hydroxynitrile lyases (HNL) catalyze the stereospecific retro-addition of a great number of aliphatic, aromatic, and heterocyclic cyanohydrines into hydrogencyanide and aldehydes or ketones, respectively (Scheme I). ${ }^{1,2}$ The enzymatic reaction from left to right in Scheme $I$ is a component of the cyanogenesis in plants. ${ }^{3}$ Release of hydrogencyanide upon damage of cells in germinating seeds or in leaves is thought to be part of a protection strategy against infectious pathogens.

Two types of lyases that vary in subunit structure, cofactor specificity, and stereoselectivity of reaction have been reported. HNL of Type I (families Olacaceae, ${ }^{4}$ Gramineae, ${ }^{5,6}$ and Luminaceae ${ }^{7}$ ) usually exist in homodimeric or heterodimeric states with subunit molecular weights between 22,000 and $42,000 \mathrm{Da}$, respectively, of which up to $9 \%$ is carbohydrate. These enzymes are cofactor independent.

The second type of HNL is found in different species of Rosaceae. ${ }^{8}$ HNLs of this group are typically single chain glycoproteins with a molecular mass ranging from 50,000 to $80,000 \mathrm{Da}$, of which up to $30 \%$ is carbohydrate. Enzymes exist in different isoforms and catalyze exclusively the decomposition of cyanohydrines in the R-configuration. Most significant for Type II HNL is the presence of the cofactor flavine-adeninedinucleotide (FAD), which is critical to the catalytic activity. ${ }^{9}$

The best studied example of this conserved class of enzymes is $(\mathrm{R})-(+)$ mandelonitrile lyase (MNL-A, EC.4.1.2.10) from almonds (Prunus amygdalus) cat- alyzing the dissociation of mandelonitrile into benzaldehyde and $\mathrm{HCN} .{ }^{10}$ The protein is a single polypeptide $\left(\mathrm{M}_{\mathrm{r}} 75,000\right)$ containing a FAD cofactor and is heavily $\mathrm{N}$-glycosylated with oligomannose units $(\mathrm{H}$. Wajand, unpublished results). The amino-acid sequence of 12 tryptic peptides derived from MNL-A comprises 177 residues of the entire sequence $(H$. Wajand, unpublished report). Recently the primary structure of the black cherry (Prunus serotina) MNL has been deduced from its cDNA. ${ }^{12}$ The sequence of the tryptic peptides of MNL-A has been aligned with respect to the black cherry sequence. It shows $98 \%$ identity and predicts a similar glycosylation pattern.

Key features of MNL-A function are: apo-MNL-A is catalytically activated with $\mathrm{FAD}^{9}$; enzyme containing reduced FAD is inactive, suggesting that the oxidation state of FAD is important with respect to the in vivo modification of enzyme activity ${ }^{12}$; spectroscopic studies give evidence that the cofactor FAD is bound near the catalytic site ${ }^{12}$; chemical modification experiments implicate an essential cystein-SH group. ${ }^{13}$ Although recent studies have established aspects of the mechanism of mandelonitrile lyase, the biological function of the FAD cofactor in the catalytic mechanism is still subject of controverse discussion. ${ }^{14}$

In addition to its physiological role, MNL-A is important as a biocatalyst in organic chemistry. ${ }^{15,16}$ The enantioselective addition of HCN to aldehydes or ketones, respectively (e.g., reaction from right to left in Scheme I), forms chiral cyanohydrines that can be transformed into optically active $\alpha$-hydroxycarbonic acids or $\alpha$-hydroxy-ketones, respectively, which are important intermediates for pharmaceuticals.

Abbrevations: PEG 4000, Polyethylene glycol 4000; HNL, Hydroxynitrile lyases; FAD, Flavine-Adeninedinucleotide; MNL-A, (R)-(+) Mandelonitrile Lyase from Almonds; MNLAI, Isoenzyme I of MNL-A; MNL-A II, Isoenzyme II of MNL-A MNL-A III, Isoenzyme III of MNL-A; MNL-A IV, Isoenzyme IV of MNL-A.

Received April 1, 1994; accepted April 6, 1994

Address reprint requests to Hanspeter Lauble, Institut für Organische Chemie und Isotopenforschung, Universität Stuttgart, D-70569 Stuttgart, Germany. 
<smiles>[R]C(O)C#N</smiles>

cyanohydrine

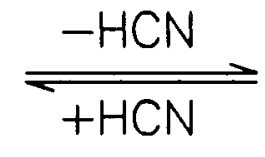

aldehyde

Scheme 1.

To understand how MNL-A and other members of this family of hydroxynitrile lyases interact stereoselectively with substrates, knowledge of their three-dimensional structure is crucial. In this paper we report crystals of almond mandelonitrile lyase suitable for a high resolution crystal structure analysis.

\section{MATERIALS AND METHODS Purification of Mandelonitrile Lyase}

Mandelonitrile lyase isoenzymes were purified to apparent homogeneity using various precipitation and chromatographic steps. Protein concentrations were determind with the BCA Protein Assay (Pierce). Mandelonitrile lyase activity was assayed according to Bové and Conn. ${ }^{17}$

Almond (Prunus amygdalus) seeds $(2 \mathrm{~kg})$ were ground and defatted by repeated treatment with about $101 \mathrm{n}$-hexane. The powder was lyophilized, resuspended in 41 water, and stirred for $24 \mathrm{~h}$. The $\mathrm{pH}$ of the suspension was adjusted continuously to 7.5 with $1 \mathrm{M}$ ammonia. The extract was centifuged at $6,000 \mathrm{~g}$ for $30 \mathrm{~min}$. The supernatant was equilibrated with $1 \mathrm{M} \mathrm{H}_{3} \mathrm{PO}_{4}$ to $\mathrm{pH} 5.4$ and left overnight at $4^{\circ} \mathrm{C}$. The resulting precipitate was again centrifuged at $6,000 \mathrm{~g}$ for $30 \mathrm{~min}$ and the supernatant was concentrated.

The enzyme extract was loaded onto a methyl p-hydroxybenzoat modified Eupergit $\mathrm{C}$ column ${ }^{18}$ (Röhm; $11.3 \times 18 \mathrm{~cm}$ ) equilibrated with $10 \mathrm{mM} \mathrm{Na}$ citrate, $\mathrm{pH} 5.4,25 \mathrm{mM} \mathrm{NaCl}$ (buffer A). After washing, the proteins were eluted with buffer A containing $500 \mathrm{mM} \mathrm{NaCl}$. The peak fractions were pooled, dialyzed against $20 \mathrm{mM}$ bis-Tris. $\mathrm{HCl}, \mathrm{pH} 6.5$ (buffer B), and loaded onto a Q-Sepharose HP column (Pharmacia; $3.5 \times 10 \mathrm{~cm}$ ) equilibrated with buffer B. After washing, a 11 linear gradient from 0 to $1 \mathrm{M}$ $\mathrm{NaCl}$ in buffer $\mathrm{B}$ was applied.

The peak fractions were combined, dialyzed against $20 \mathrm{mM}$ piperazine $\cdot \mathrm{HCl}, \mathrm{pH} 5.5$ (buffer $\mathrm{C}$ ), and loaded onto a PBE-94 column (Pharmacia; $1 \times$ $35 \mathrm{~cm}$ ) equilibrated with buffer $\mathrm{C}$. The $\mathrm{pH}$ gradient for chromatofocusing was formed with $150 \mathrm{ml}$ of 25
$\mathrm{mM}$ piperazine $\cdot \mathrm{HCl}, \mathrm{pH} 4.0,10 \%$ polybuffer $74-\mathrm{HCl}$ (Pharmacia). Proteins were eluted with the same buffer; fractions with enzyme activity were dialyzed against $20 \mathrm{mM}$ piperazine $\cdot \mathrm{HCl}, \mathrm{pH} 5.5$ and concentrated.

Proteins were loaded onto a Q-Sepharose HP column (Pharmacia; $3.5 \times 10 \mathrm{~cm}$ ) equilibrated with buffer $\mathrm{C}$. The mandelonitrile lyase isoenzymes were eluted from the column as single peaks by applying a 2.91 linear $\mathrm{NaCl}$ gradient $(0-250 \mathrm{mM} \mathrm{NaCl})$ in buffer C (Fig. 1A). Eluted fractions with enzymatic activity appeared homogeneous on Coomassie-blue stained sodium dodecyl sulfate/polyacrylamide gel electrophoresis (SDS/PAGE) (Fig. 1B).

The majority of the enzymatic activities were eluted at $68 \mathrm{mM} \mathrm{NaCl}$ [isoenzyme III (MNL-A III)] and $80 \mathrm{mM} \mathrm{NaCl}$ [isoenzyme IV (MNL-A IV)], respectively. Minor portions of the activities were eluted at $55 \mathrm{mM} \mathrm{NaCl}$ [isoenzyme I (MNL-A I)] and $62 \mathrm{mM} \mathrm{NaCl}$ [isoenzyme II (MNL-A II)], respectively. Differences of the isoenzymes concerning their elution properties might arise from variations in their primary structure and/or from heterogeneity in their carbohydrate contents. The isoenzyme samples were dialyzed against $10 \mathrm{mM}$ Na-citrate, $\mathrm{pH} 5.4$, and concentrated to $20 \mathrm{mg} / \mathrm{ml}$ using an Amicon concentrator with YM10 membrane.

\section{Crystallization Procedure and X-Ray Diffraction Studies}

The crystallization experiments were performed at $20^{\circ} \mathrm{C}$ using the hanging drop vapor diffusion method. ${ }^{19}$ Drops containing $4 \mu \mathrm{l}$ of $16 \mathrm{mg} / \mathrm{ml}$ protein solution in $10 \mathrm{mM} \mathrm{Na-citrate,} \mathrm{pH} 5.4$, and $4 \mu \mathrm{l}$ of precipitant buffer were prepared on siliconized coverslips and suspended over $0.7 \mathrm{ml}$ precipitant buffer. The best reservoir conditions for crystallization were $100 \mathrm{mM}$ Tris. $\mathrm{HCl}$, pH 7.4, 20\% PEG 4000, 18\% isopropanol, $0.02 \% \mathrm{NaN}_{3}$.

For X-ray studies crystals were transformed into a stabilizing solution containing $100 \mathrm{mM}$ Tris. $\mathrm{HCl}$, pH 7.4, 20\% polyethylene glycol (PEG) 4,000, 23\% isopropanol, and carefully washed. Crystals were 

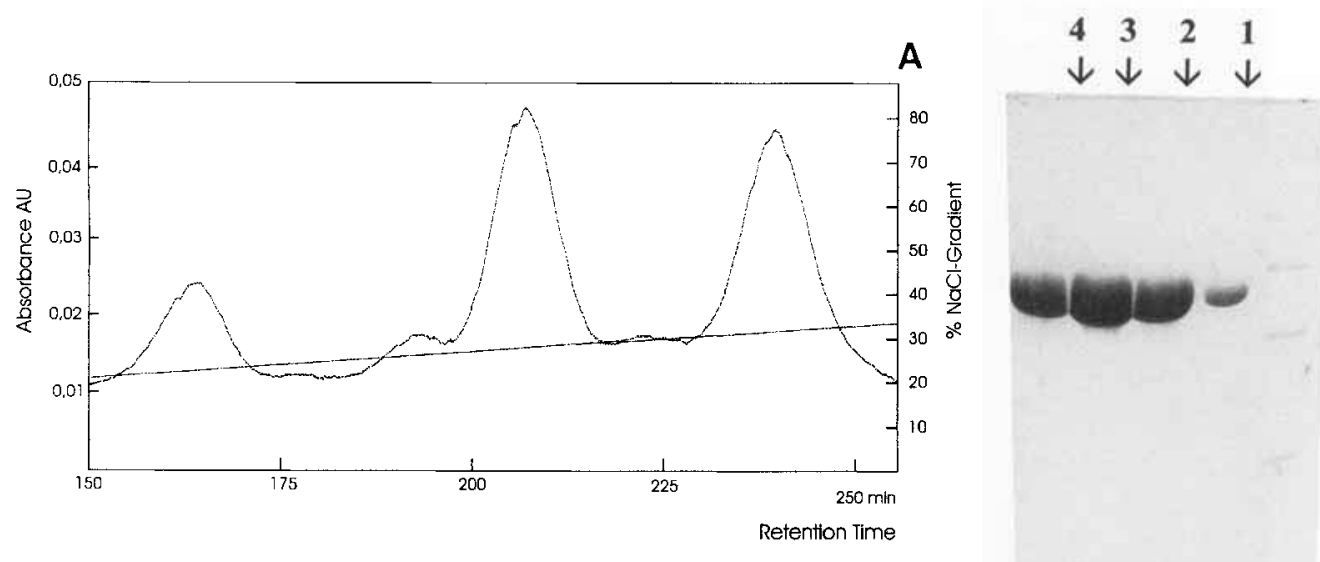

B

$\leftarrow 116.000 \mathrm{Da}$

$\leftarrow 97.400 \mathrm{Da}$

$\leftarrow 66.200 \mathrm{Da}$

$\leftarrow 31.000 \mathrm{Da}$

Fig. 1. Purification of mandelonitrile lyase (MNL-A) isoenzymes. A: Elution profile of MNL-A isoenzymes on Q-Sepharose $\mathrm{HP}$ column. Active fractions from chromatofocusing PBE-94 column were dialyzed against buffer $\mathrm{C}$ to remove polybuffer $74-\mathrm{HCl}$ and applied to Q-Sepharose HP column. The eluation profile is shown by the continuous line, and the $\mathrm{NaCl}$ gradient is indicated

mounted into glass capillaries and the capillaries were sealed with epoxy resin.

Crystal characterization was performed with an Enraf-Nonius FAST area detector system and MADNES ${ }^{20}$ using graphite monochromatized $\mathrm{CuK}_{\alpha}$ radiation produced with a $\mathrm{FR} 571$ rotating anode generator operating at $45 \mathrm{kV}$ and $65 \mathrm{~mA}$. The threedimensional data set was collected with a MAR-Research image plate and IPMOSFLM ${ }^{21}$ also using graphite monochromatized $\mathrm{CuK}_{\alpha}$ radiation produced with a FR 571 rotating anode generator operating at $45 \mathrm{kV}$ and $80 \mathrm{~mA}$. The crystal to detector distance was $130 \mathrm{~mm}$ and data were collected in oscillation ranges of $1.5^{\circ}$ with 20,000 counts/image.

\section{RESULTS}

Crystals of almond mandelonitrile lyase were grown by hanging drop vapor diffusion. Initial crystallization conditions were established by variation of $\mathrm{pH}$, protein concentration, temperature and nature of percipitants. Small, thin, plate-shaped, yellow crystals of MNL-A II, MNL-A III, and MNL-A IV appeared after 4 weeks using a reservoir of 100 $\mathrm{mM}$ Tris $\mathrm{HCl}, \mathrm{pH} 7.4,20 \%$ PEG 4,000, $18 \%$ isopropanol, $0.02 \% \mathrm{NaN}_{3}$ (Fig. 2A). Crystals grew to their maximum size of $0.8 \mathrm{~mm} \times 0.3 \mathrm{~mm} \times 0.2 \mathrm{~mm}$ within 2 months. They show a pronounced tendency towards twinning and, furthermore, crystallization trials using the conditions described were not always successful. Using a fine grid of conditions centered around the one described above has shown that the most critical factor for crystallization seems to be the concentration of the co-precipitant isopropanol. The crystallization of HNL-A isoenzyme, however, remains problematic mainly because of its extreme glycosylation. by the dashed line. B: SDS/15\% PAGE analysis of MNL-A isoenzymes. The eluted, active peak fractions from the Q-Sepharose were pooled and concentrated. Isoenzyme numbers are indicated above the gel. Molecular masses of marker proteins are shown at right.

The unit cell dimensions of the crystals were determined from 155 reflections using MADNES. ${ }^{20}$ The data indicated that the crystals belong to the monoclinic space groups of either $\mathrm{P} 2$ or $\mathrm{P} 2{ }_{1}$ with unit cell dimensions $\mathrm{a}=69.9 \AA, \mathrm{b}=95.1 \AA \mathrm{A}, \mathrm{c}=$ 95.6 $\AA$, and $\beta=118.5^{\circ}$. Further characterization of the crystals by precession photographs only showed reflections of type $0 \mathrm{k} 0$ to be present if $\mathrm{k}=2 \mathrm{n}$, compatible with space group $\mathrm{P} 2{ }_{1}$. Assuming two molecules of mandelonitrile lyase with a molecular weight of $75,000 \mathrm{Da}$ in the asymmetric unit, the volume per unit mass is $2.1 \AA^{3} / \mathrm{Da}$, within the range observed for a standard set of proteins. ${ }^{22}$ The solvent content of the crystals is about $40 \%$. Moderate anisotropy of $\mathrm{x}$-ray intensities was observed with a maximum resolution of $2.5 \AA$ along the $\mathrm{a}^{*}$-axis. Crystals are fairly resistant to decay upon $x$-ray irradiation.

A native x-ray data set was collected to $2.6 \AA \AA$ resolution from a single crystal. Data were recorded with a MAR Research image plate detector (Fig. 2B) and processed with IPMOSFLM. ${ }^{21}$ A total of 55,287 observations was merged to give 31,388 unique reflections. Between 20 and $2.6 \AA$ resolution, $92.9 \%$ of the possible reflections have been recorded with an $R_{\text {sym }}$ (I) of 0.099. Completeness in the highest resolution shell $(2.7-2.6 \AA)$ is $79 \%$ with an average $\mathrm{I} / \sigma$ (I) greater than 3 . Heavy atom derivatives are currently being screened.

\section{ACKNOWLEDGMENTS}

We are greatful to Prof. W. Saenger for using data collection facilities in Berlin and to Dr. U. Heinemann for support, advice and critical reading of the manuscript. This work was supported in part by a 

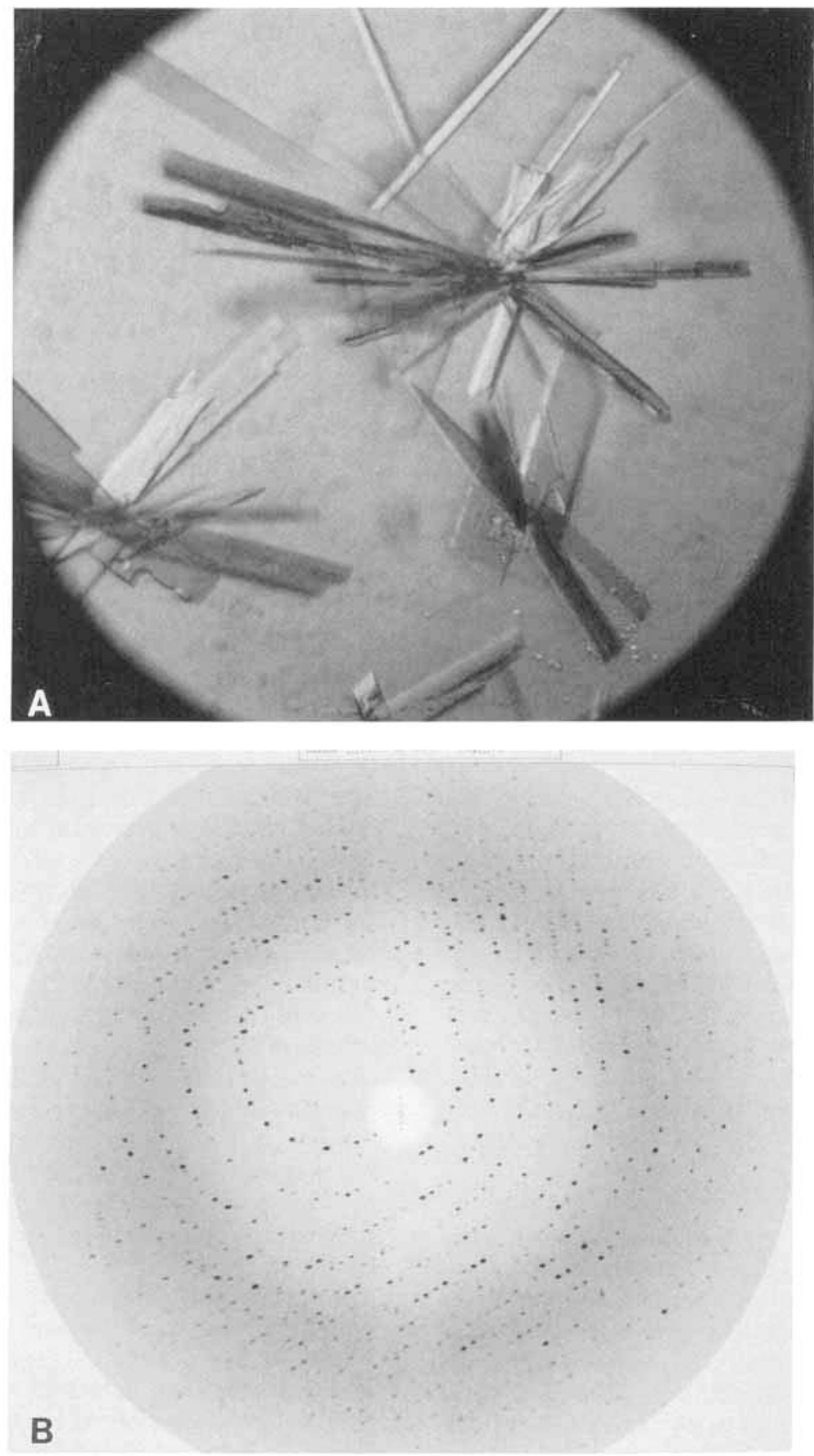

Fig. 2. Photographs of crystals and diffraction pattern of mandelonitrile lyase of almonds (MNL-A). A: Monoclinic crystals of MNL-A grown from PEG 4,000-isopropanol. B: X-ray diffraction diagram of mandelonitrile lyase isoenzyme III recorded on a MAR image plate detector; wavelength, $1.5418 \AA_{;}$crystal to film distance, $130 \mathrm{~mm}$; exposure time, $10 \mathrm{~min}$; oscillation range, $1.5^{\circ}$. Maximum resolution range in this picture is $2.3 \AA$.

grant from the Bundesministerium für Forschung und Technologie under A03U and A10U.

\section{REFERENCES}

1. Gerstner, E., Pfeil, E. Zur Kenntnis des Flavoenzyms Hydroxinitril-Lyase (D-Oxynitrilase). Hoppe-Seylers Z. Physiol. Chem. 353:271-286, 1972
2. Seigler, D.S. Isolation and characterization of naturally occuring cyanogenic compounds. Phytochemistry 14:9-29, 1975.

3. Poulton, J.E. Cyanogenic compounds in plants and their toxic effects. In: "Handbook of Natural Toxins. Vol. I, Plant Toxins." Tu, A.T., Keeler, R.F., eds. New York: Marcel Dekker, 1983:117-157.

4. Kuroki, G.W., Conn, E.E. Mandelonitrile lyase from $X i$ - 
menia americana L: Stereospecifity and lack of flavin prosthetic group. Proc. Natl. Acad. Sci. USA. 86:6978-6981, 1989.

5. Seely, M.K., Criddle, R.S., Conn, E.E. The metabolism of aromatic compounds in higher plants. J. Biol. Chem. 241: 4457-4462, 1966

6. Wajant, H., Mundry, K. Hydroxynitrile lyase from Sorghum bicolor: A glycoprotein heterotetramer. Plant Sci. 88:127-133, 1993.

7. Xu, L., Singh, B.K., Conn, E.E. Purification and characterization of aceton cyanohydrin lyase from Linum usita tissimum. Arch. Biochem. Biophys. 263:256-263, 1988.

8. Gerstner, E., Mätzke, V., Pfeil, E. Zur chemischen und biologischen Systematik der Rosaceen. Naturwissenschaften 55:561-563, 1961

9. Bärwald, K., Jaenicke, L. D-hydroxynitrile lyase: Involvement of the prosthetic flavine adenine dinucleotide in enzyme activity. FEBS Lett. 90:255-260, 1978.

10. Becker, W., Pfeil, E. Über das Flavinenzym D-Oxynitrilase. Biochem. Z. 346:301-321, 1966.

11. Cheng, I., Poulton, J.E. Cloning of DNA of Prunus serotina (R) $-(+)$ mandelonitrile lyase and identification of a putative FAD-binding site. Plant Cell Physiol. 34:1139-1143, 1993.

12. Jorns, M.S. Mechanism of catalysis by the flavoenzyme oxynitrilase. J. Biol. Chem. 254:12145-12152, 1979.

13. Jaenicke, L., Preun, J. Chemical modification of hxdroxynitrile lyase by selective reaction of an essential cystein-SH group with $\alpha, \beta$-unsaturated propiophenones as pseudo-substrates. Eur. J. Biochem. 138:319-325, 1984.
14. Jorns, M.S. Comments on "Chemical modification of hxdroxynitrile lyase by selective reaction of an essential cystein-SH group with $\alpha, \beta$-unsaturated propiophenones as pseudo-substrates." Eur. J. Biochem. 146:481-482, 1985.

15. Smitskamp-Wilms, E., Brussee, J., van der Gen, A., van Scharrenburg, G.J.M., Sloothaak, J.B. Hydroxynitrile lyases from almond and sorghum as biocatalysts. Recl. Trav. Chim. Pays-Bas 110:209-215, 1991.

16. Effenberger, F., Ziegler, T., Förster, S. Enzymkatalysierte Cyanhydrin Synthese in organischen Lösungsmitteln. Angew. Chemie 99:491-492, 1987.

17. Bové, C., Conn, E.E. Metabolism of aromatic compounds in higher plants. J. Biol. Chem. 236:207-210, 1961.

18. Kaul, R., Mattiason, B. Affinity elution of almond oxynitrilase from an affinity support based on Eupergit C. Biotechnol. Appl. Biochem. 9:294-302, 1987.

19. McPherson, A. The growth and preliminary investigation of protein and nucleic acid crystals for x-ray diffraction analysis. Methods Biochem. Anal. 23:249-345, 1976.

20. Messerschmidt, A., Pflugrath, J.W. Crystal orientation and $x$-ray pattern prediction routines for area-detector diffractometer systems in macro-molecular crystallography. J. Appl. Crystallogr. 20:306-315, 1987.

21. Leslie, A.G.W. Recent changes to the MOSFLM package for processing film and image plate data. Joint CCP4 and ESF-EACBM Newsletters on Protein Crystallography 26, 1992.

22. Matthews, B.W. Solvent content of protein crystals. J. Mol. Biol. 33:491-497, 1968. 